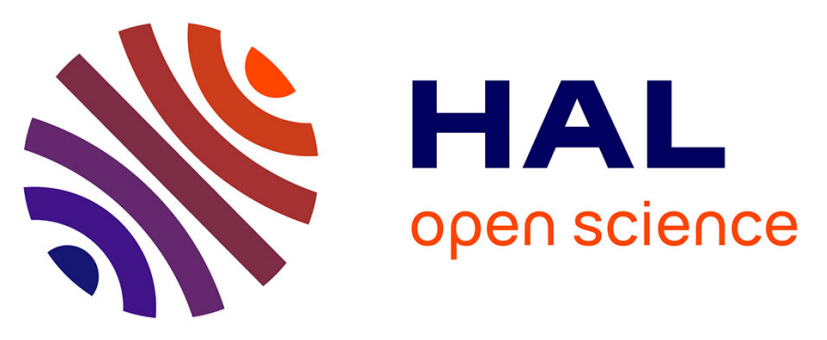

\title{
PRELIMINARY STUDY OF SURFACE TREATMENTS FOR PLATINUM ELECTRODES DESIGNED FOR OXIDATION-REDUCTION POTENTIAL DETERMINATIONS IN ACTIVATED SLUDGE
}

\author{
Alain Heduit, Bénédicte Martin, Daniel R. Thevenot
}

\section{To cite this version:}

Alain Heduit, Bénédicte Martin, Daniel R. Thevenot. PRELIMINARY STUDY OF SURFACE TREATMENTS FOR PLATINUM ELECTRODES DESIGNED FOR OXIDATION-REDUCTION POTENTIAL DETERMINATIONS IN ACTIVATED SLUDGE. Water Science and Technology, 1994, 30 (4), pp.239 - 242. hal-01179751

\author{
HAL Id: hal-01179751 \\ https://hal.science/hal-01179751
}

Submitted on 24 Jul 2015

HAL is a multi-disciplinary open access archive for the deposit and dissemination of scientific research documents, whether they are published or not. The documents may come from teaching and research institutions in France or abroad, or from public or private research centers.
L'archive ouverte pluridisciplinaire HAL, est destinée au dépôt et à la diffusion de documents scientifiques de niveau recherche, publiés ou non, émanant des établissements d'enseignement et de recherche français ou étrangers, des laboratoires publics ou privés. 


\title{
PRELIMINARY STUDY OF SURFACE TREATMENTS FOR PLATINUM ELECTRODES DESIGNED FOR OXIDATION-REDUCTION POTENTIAL DETERMINATIONS IN ACTIVATED SLUDGE
}

\author{
Alain Heduit*, Bénédicte Martin* and \\ Daniel R. Thevenot** \\ * Centre National du Machinisme Agricole, du Génie Rural, des Eaux et des Forêts \\ (CEMAGREF), Divison Qualité des Eaux, 14 avenue de Sint-Mandé, 75012 Paris, \\ France. \\ ** Université Paris XII, Val de Marne (U.P.V.M.), Faculté de Sciences et \\ Technologie, Laboratoire de Bioélectrochimie et Analyse du Milieu (LABAM), 61, \\ avenue du Général de Gaulle, 94010 Créteil Cedex, France
}

\begin{abstract}
Platinum electrodes with six different surface treatments (polishing, platinization, polypyrrole, polyurethane, cellulose acetate and Nafion) were tested for equilibrium exchange current densities and zero-current potential in treated water and activated sludge. Preliminary results show that platinization and polypyrrole treatment increase electron transfer rates, but polypyrrole film breaks up rapidly in activated sludge; polyurethane and cellulose acetate layers did not prevent fouling (and impaired performance) in activated sludge, but Nafion seemed more promising.
\end{abstract}

\section{KEYWORDS}

Electochemistry; platinum electrodes; oxidation-reduction potential; activated sludge.

\section{INTRODUCTION}

Platinum electrodes were shown to be potentially usable for the real-time monitoring of nitrification and denitrification processes in sewage treatment plants (Wouters-Wasiak et al., 1993; Wareham et al., 1994). They are much more sensitive to the redox variations of the environment than gold electrodes (Heduit $e t$ al., 1993). Nevertheless, their use remains difficult due to the slow reaction rates at the interface and adsorption of species on the platinum surface (Heduit and Thevenot, 1992).

The increase of the electron exchange rates was attempted by a redox polymer layer obtained by Pyrrole electropolymerization on platinum (Polypyrrole) (Umana and Waller, 1986; Ikariyama et al., 1987) and by electrolytic deposit of platinum black (platinization) intended to increase the rugosity and the active surface of the metal. Discrimination by size of the species capable of reaching the platinum was attempted by a 
polyurethane layer (Bindra et al., 1991), discrimination by size and (negative) charge by cellulose acetate (Wang et al., 1988; Bindra et al., 1991) or Nafion (Harisson et al., 1988) layers.

\section{METHODS}

The electrochemical kinetics were assessed from the equilibrium exchange current densities determined by low-speed $(1 \mathrm{mV} / \mathrm{s})$ plotting of the potential-intensity curves (anode and cathode scans around the equilibrium potential) in treated water or aerated activated sludge and by plotting of the Tafel lines $|\mathrm{i}| v s$ $\left(E-E_{i}=0\right)$. The zero-current potentials were measured against a Saturated Calomel Electrode (SCE) using a high-impedance input millivoltmeter.

The exchange current densities and zero-current potentials determination were performed under the following conditions.

1. Immediately after treatment of the platinum surfaces (polishing, the mineral or organic deposit).

2. After treatment and immersion of the electrodes for 7 days in activated sludge alternately submitted to aerobic and mild anoxic conditions (> $100 \mathrm{~m} / \mathrm{VSCE})$.

3. After treatment and immersion of the electrodes for 24 hours in activated sludge maintained in anaerobiosis (- $200 \mathrm{mV} / \mathrm{SCE})$.

\section{RESULTS}

Immediately after treatment of the platinum surface, the highest equilibrium exchange current densities were obtained with platinized electrodes or those coated with polypyrrole (Figure 1). Significantly lower rates were observed for the polished electrodes or those coated with cellulose acetate of Nafion. The polyurethane deposit gave the lowest exchange rate densities $\left(<0.1 \mu \mathrm{A} . \mathrm{cm}^{2}\right)$.

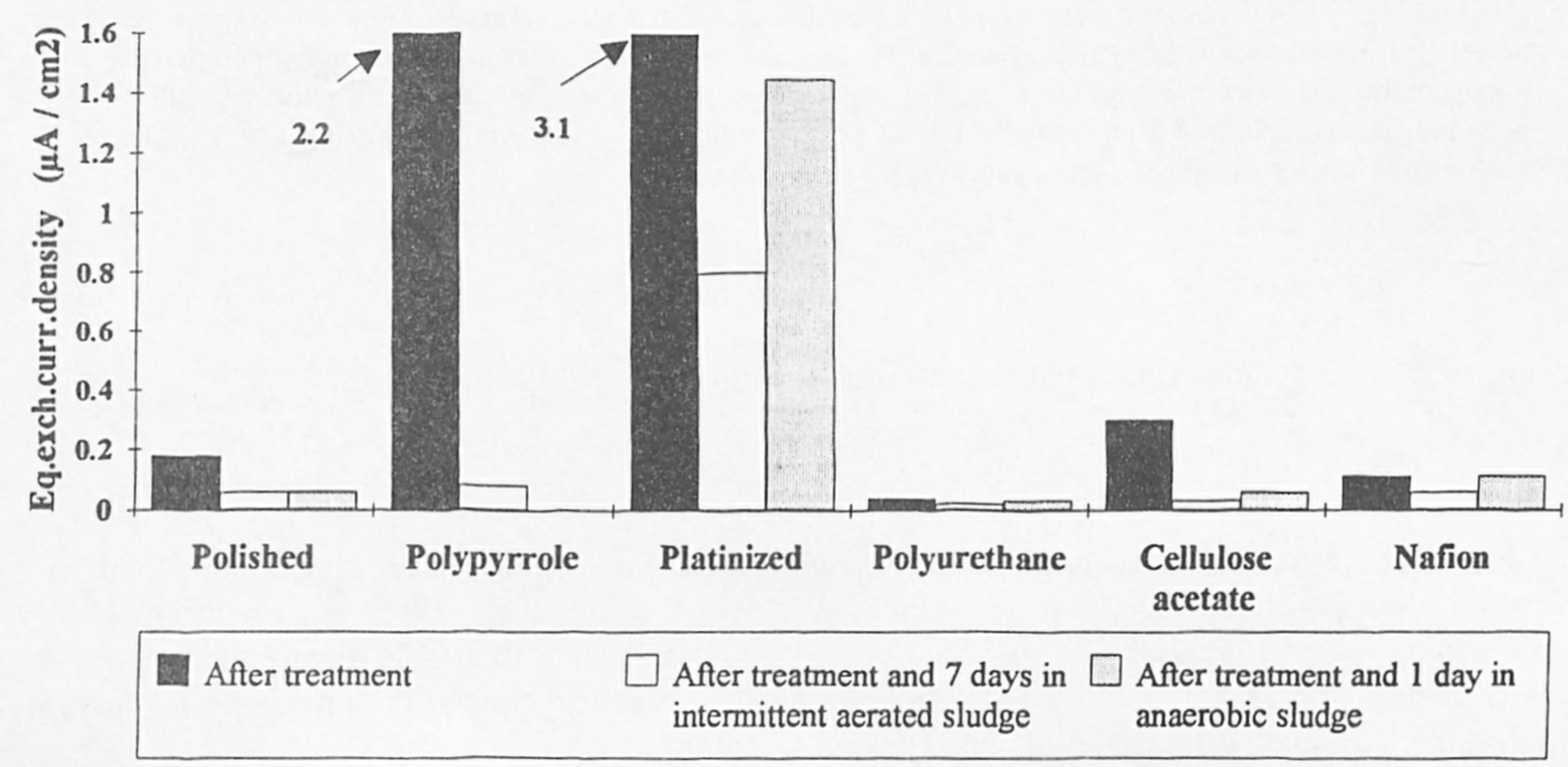

Fig. 1. Equilibrium exchange current densities in treated water or aerated activated sludge.

The equilibrium exchange current densities obtained after immersion of these treated Pt electrodes in the activated sludge alternately submitted to aerobic and anoxic sequences during 7 days reached only $10 \%$ to 
$55 \%$ of the initial current densities, with the exception of the polypyrrole layer (4\%) which broke up rapidly in activated sludge.

After immersion of the electrodes in the anaerobic activated sludge, the exchange current densities obtained reached only $20 \%$ to $50 \%$ of the initial current densities, with the exception of Nafion. The platinized platinum electrode was found to maintain the highest equilibrium exchange current density value (1.45 $\left.\mu \mathrm{A} / \mathrm{cm}^{2}\right)$.

Immediately after Pt electrode treatment, the highest zero-current potentials were obtained after polishing or Nafion deposits (Figure 2). For the other deposits, potentials were found to be lower.

After immersion of the electrodes in the activated sludge alternately submitted to aerobic and anoxic sequences, the deviations from the former potentials were quite small for the polished electrodes and those coated with polypyrrole or Nafion. For the other deposits, the values observed were higher than the values observed immediately after treatment of the platinum surfaces.

When placed in anaerobiosis for 24 hours, potential show an under-estimation of approximately $200 \mathrm{mV}$ when these electrodes were again dipped in an aerated solution, except for NAfion for which the drift was much lower $(100 \mathrm{mV})$.

All these potentials are nevertheless significantly lower than equilibrium potential calculated, taking into account dissolved oxygen and $\mathrm{pH}$ within treated water or aerated sludge used for comparison $(>700 \mathrm{mV})$ (Heduit and Thevenot, 1989).
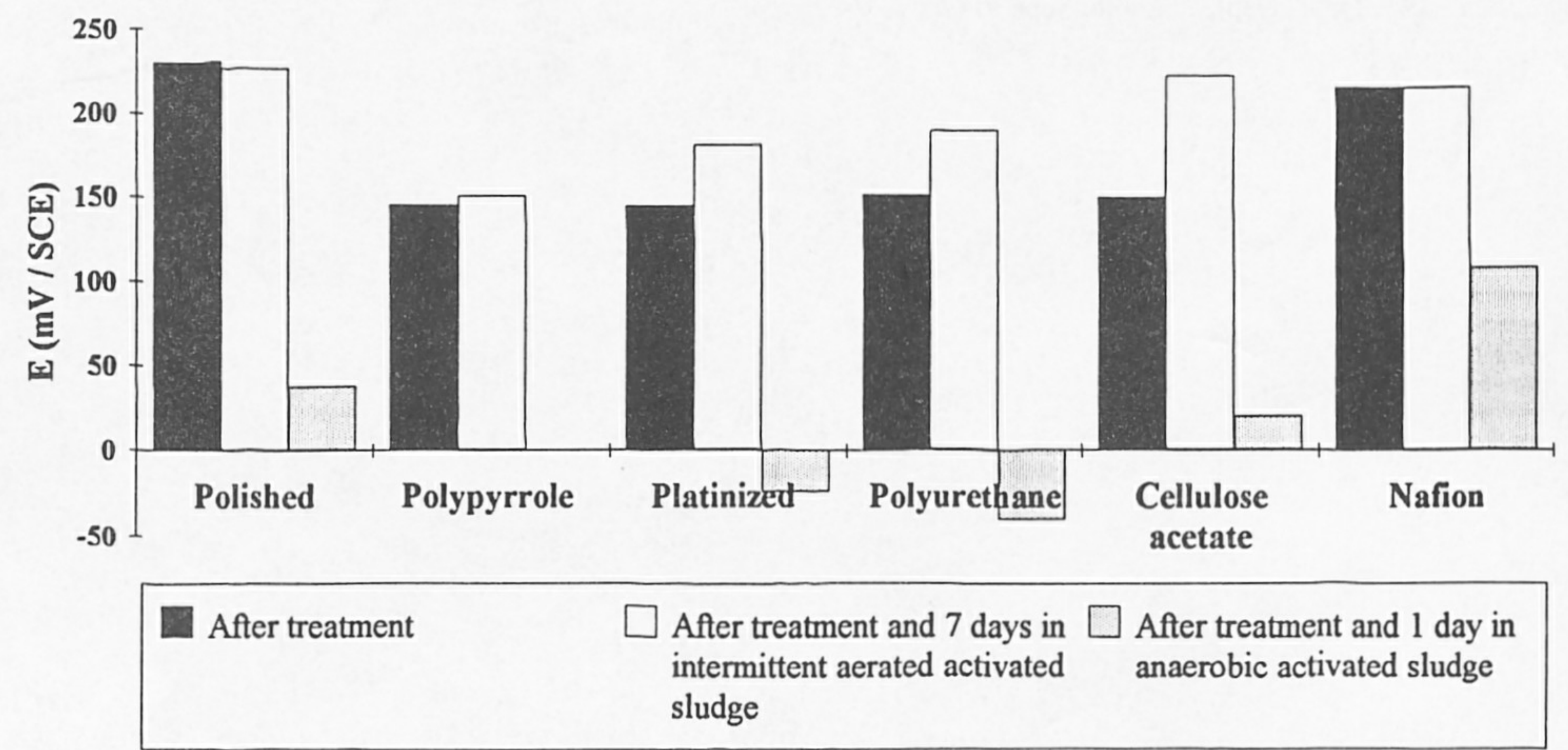

Fig. 2. Zero-current potentials in treated water or aerated activated sludge.

\section{CONCLUSION}

These preliminary studies show that the electrolytic deposits of platinum black or polypyrrole resulted in a significant increase of the electron transfer rates but that polypyrrole film was found to break up rapidly in activated sludge.

Under these experimental conditions, polyurethane and cellulose acetate layers did not prevent the platinum surface from fouling activated sludge: this contamination led to a decrease of the electron transfer rate and an under-estimation of the potentials when dipped into anaerobic sludge. Nafion deposit seems to decrease this drift and could be valuable in activated sludge; further study is in progress. 


\section{ACKNOWLEDGEMENTS}

The present work was supported by grant no, EV5V-CT93-0245 from the EEC Environment Program.

\section{REFERENCES}

Bindra, D. S., Zhang, Y., Wilson, G. S., Sternberg, R., Thevenot, D. R., Moatti, D. and Reach, G. (1991). Design and in vitro studies of a needle type glucose sensor for subcutaneous monitoring. Anal. Chem. 63, 1692-1696.

Harisson, J., Turner, F. B. and Baltes, H. P. (1988). Characterization of perfluorosulfonic acid polymer coated enzyme electrodes and a minaturized integrated potentiostat for glucose analysis in whole blood. Anal. Chem. 60, 2002-2007.

Heduit, A. and Thevenot, D. R. (1989). Relation between redox potential and oxygen levels in activated sludge reactors. Wat. Sci. Tech. 21(8-9), 947-956.

Heduit, A. and Thevenot, D. R. (1992). Elements of interpretation of platinum electrode potentials in biological treatment. Wat. Sci. Tech. 26(5-6), 1335-1344.

Heduit, A., Martin, B., Duchamp, I. and Thevenot, D. R. (1993). Comparison of gold and platinum electrode responses in activated sludge. Wat. Sci. Tech. 28(11-12), 473-480.

Ikariyama, Y., Galiatsatos, C., Heineman, W. R. and Yamauchi, S. (1987). Polypyrrole electrode as a detector of anionic substances. Senors and Actuators, 12, 455-461.

Umana, M. and Waller, J. (1986). Protein modified electrodes. The glucose oxidse/polypyrrole system. Anal. Chem. 58, 29792983.

Wang, J., Golden, T. and Li, R. (1988). Cobalt phthalocyananine/cellulose acetate chemically modified electrodes for electrochemical detection in flowing streams. Multifunctional operation based upon the coupling of electrocatalysis and permselectivity. Anal. Chem. 60, 1642-1645.

Wareham, D. G., Mavinic, D. S. and Kenneth, J. H. (1994). Sludge digestion using ORP-regulated aerobic-anoxic cycles. Wat. Res. 28, 373-384.

Wouters-Wasiak, K., Heduit, A., Audic, J. M. and Lefevre, F. (1993). Oxidation-reduction potential (ORP) control of the aeration in a wastewater treatment plant: Nitrogen removal efficiency. A case study: the Benfeld treatment plant. Proc "forum for applied technology", Gent, Belgium, Sept 30-Oct 1. 